\title{
IMPACT OF OIL PRICES ON STOCK RETURNS: EVIDENCE FROM PAKISTAN'S STOCK MARKET
}

\author{
Zeeshan Atiq ${ }^{*}$ \\ Muhammad Farhan ${ }^{* *}$
}

\begin{abstract}
Very few studies have investigated the movement in stock returns that result due to changes in oil prices. In recent years due to cooling down of China, unveiled oil reserves of Iran, decreasing demand worldwide and discovery of shale gases the world has experienced a large fall in the oil prices. These changes are also affecting performance of manufacturing and other associated companies in countries all over the world. Pakistan has also been affected by these changes in many ways. Especially, the returns on stock markets have been affected a lot by the variations in the oil prices. This paper using monthly data set from years 2014 to 2016 of the non-financial firms operated in Pakistan Stock Exchange (PSX), investigates the effect of variation in oil prices on returns on stock. Results from the panel data analysis indicate a negative relationship between the variables. Since, Pakistan is an oil importing, movement in the prices contribute towards affecting the production cost in a positive manner which in turn affects the execution of the enterprises as well as returns of the stocks negatively.
\end{abstract}

JEL Classifications:

Q41;G12; Q43; O14

Keywords: Oil prices, stock returns, manufacturing sector, demand, import, enterprises

\section{Introduction}

Economic growth of the oil dependent country may get affected by variations in oil prices. After a stable period between 1986 and 2006, the oil prices have had a very volatile movement. They rose from $\$ 60$ to $\$ 145$ between 2007 and 2009 and then the world witnessed unprecedented fall of oil prices, which took it to the price of mere $\$ 30$ a barrel. There are many factors that were responsible for that fall in oil prices. For instance, increase in supply of crude oil due to the production of shale gas and excessive production of oil in Middle East. Iraq and Libya kept their oil production up regardless of their political shakiness. Saudi Arabia did not reduce its productions due to the economic and political reasons. Another important reason was that China saw corrections in its growth rate, there was recession in Japan, and European countries like Germany faced serious economic downturn. These were the factors that are deemed responsible for fall

\footnotetext{
* Zeeshan Atiq, Ph.D. Assistant Professor, Department of Economics, University of Karachi ** Muhammad Farhan, Assistant Professor, Pakistan Navy School of Logistics, Karsaz Faisal Cantonment, Karachi, Karachi City, Sindh
} 
of demand of oil all over the world. Along with the supply and demand dynamics, the world also learned to live more efficiently and environment friendly. Now the oil has been replaced with more environment friendly fuels like bio fuels, etc.

Historically, changes in oil prices have caused much of the economic turbulence during the last few years. A very small literature is available that investigates the effect of change in oil price on economic factors and stock return of the companies that are directly or indirectly influenced by the movements in oil prices. Research related to oil price changes and returns on stock have shown diverse results for on oil importing countries from oil exporting countries. In case of oil importing countries oil price volatility directly affects the economic activity of the country (see Hamilton (1983) ${ }^{1}$, Ferson and Harvey $\left.(1995)^{2}\right)$. A large literature shows that there is a great importance of the price of crude oil on stock market return (see Jones and Kaul (1996) ${ }^{3}$; Abel and Bernanke $\left.(2001)^{4}\right)$. There is even smaller literature available showing linkage between oil price movement and stock return for net oil importing countries see for example, Jordan and Lebanon ${ }^{56}$. Similarly, very limited research is available on sectoral level. Most of the available studies have used the data of US stock market to investigate (Broadstock and Filis, 2014 ${ }^{7}$ ) in Europe (Arouri et al., 2012 ${ }^{8}$ ) in Jordan (Bouri et al. 2016 ${ }^{9}$ ) and in Pakistan impact of changes in oil and gas prices on stock returns of energy incentive industries had been investigated previously. ${ }^{10}$

Theoretically, changes in oil prices affect the stock returns. The cash flows are directly or indirectly affected by changes in oil prices. Especially, if a country is an oil importing an increase in oil prices leads to increase in cost of productions and thus, reduces cash flows of the companies. Recent literature available in Pakistan only determines the effect of changes in oil price on stock return for only oil and gas sector on quarterly data (see for example Arshad and Bashir, 2015 ${ }^{11}$ ).

${ }^{1}$ Hamilton, James D. "Oil and the macroeconomy since World War II.” Journal of political economy 91, no. 2 (1983): 228-248.

${ }^{2}$ Ferson, Wayne E., and Campbell R. Harvey. "Predictability and time-varying risk in world equity markets." Research in Finance 13 (1995): 25-88.

${ }^{3}$ Jones, Charles M., and GautamKaul.”Oil and the stock markets." The journal of Finance 51, no. 2 (1996): 463491.

${ }^{4}$ Abel, Andrew B., and Ben S. Bernanke.”Macroeconomics, 4.bs.” Boston, San Francisco, (New York: Addison Willey Longman inc., 2001), pp.634-670

${ }^{5}$ Bouri, Elie. a "Return and volatility linkages between oil prices and the Lebanese stock market in crisis periods." Energy 89 (2015): 365-371

${ }^{6}$ Bouri, Elie. b "A broadened causality in variance approach to assess the risk dynamics between crude oil prices and the Jordanian stock market.” Energy Policy 85 (2015): 271-279.

${ }^{7}$ Broadstock, David C., and George Filis. "Oil price shocks and stock market returns: New evidence from the United States and China." Journal of International Financial Markets, Institutions and Money 33 (2014): 417 433.

${ }^{8}$ Arouri, Mohamed El Hedi, Jamel Jouini, and DucKhuong Nguyen. "On the impacts of oil price fluctuations on European equity markets: Volatility spillover and hedging effectiveness.” Energy Economics 34, no. 2 (2012): 611-617.

${ }^{9}$ Bouri, Elie, Basel Awartani, and AkthamMaghyereh. "Crude oil prices and sectoral stock returns in Jordan around the Arab uprisings of 2010." Energy Economics 56 (2016): 205-214

${ }^{10}$ Arshad, RABIA., and ADNAN. Bashir. "Impact of oil and gas prices on stock returns: Evidence from

Pakistan's energy intensive industries." International Review of Social Sciences 3, No. 4 (2015): 156-168

${ }^{11}$ Ibid. 


\section{Importance of crude oil in Pakistan}

Pakistan heavily relies on oil and gas resources. Variations of oil prices, therefore, affect performance of Pakistan's economy. In Pakistan, oil import is 33\% of Pakistan's aggregate imports. A variation in oil cost has always an impact on national exchequer. For example, fall in the oil prices derives down the bill of imports and therefore, improves balance of payment conditions. In 2014-15, the bill of oil import came down from $\$ 15.36$ billion in 2013-14 to $\$ 11.86$ billion (Economic survey of Pakistan 2014$15^{12}$ ), a $22.8 \%$ decrease. This caused decline in the current account deficit and put a positive impact on availability of foreign exchange savings.

Low worldwide crude oil prices are the restrictive motivating factors for the upstream oil sectors (see Fig 1), which result in the fall of exploration of oil. This cause fall in investment in local oil production. Low crude oil prices from 2014 to 2016 have adversely affected the price of PSO share. In like manner, the offer cost of OGDCL declined by 63 percent during the period between 2014-2016 (OGRA Annual Report $\left.2015-16^{13}\right)$.

Thus Pakistan needs to import vast amount of oil and oil based items from Middle East nations particularly from Saudi Arabia. In financial year 2015-16 consumption of different oil products increases by 5.2 percent during the year 2014-15 (OGRA Annual Report 2015-16 ${ }^{14}$.

Figure-1 Prices of crude oil

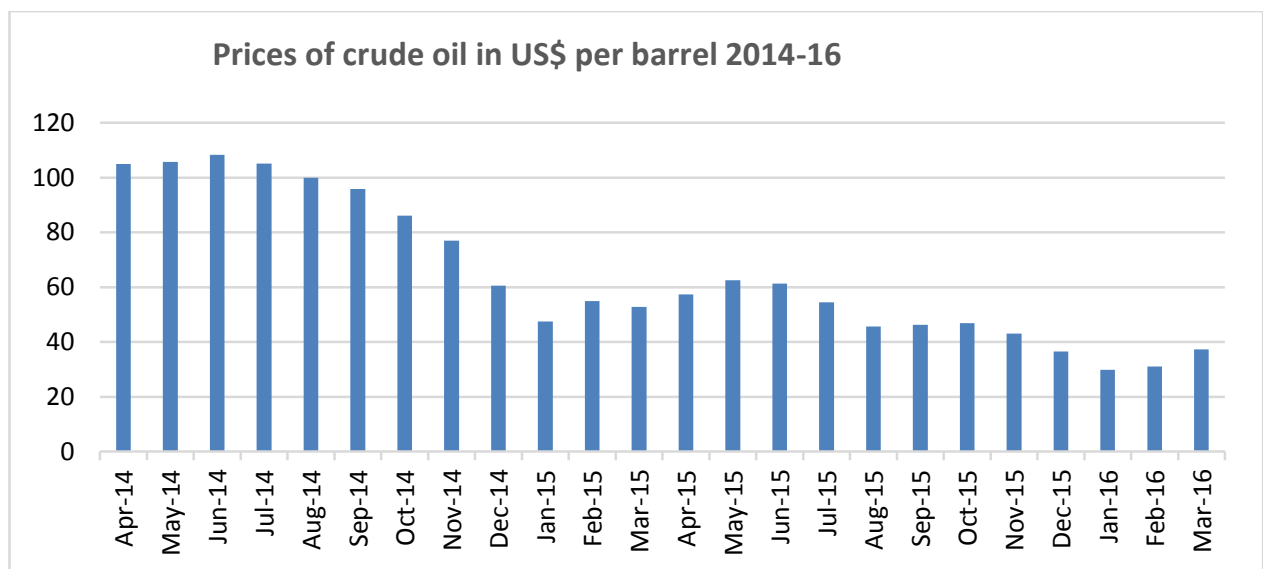

Source: OGRA ${ }^{15}$

\footnotetext{
12،"Economic Survey of Pakistan 2014-15.” Islamabad: Government of Pakistan (2015). http://www.finance.gov.pk/survey_1617.html (accessed July 14, 2017).

${ }^{13}$ OGRA-Oil and Gas Regulating Authority (2016).Annual Report (2015-16).https://www.ogra.org.pk/ograannual-reports (accessed July 20, 2017).

${ }^{14}$ Ibid.

${ }^{15}$ Ibid.
} 
The rest of the paper is structured as follows: Section 2 presents the literature review; Section 3 contains data and methodology. Section 4 presents the findings. Conclusion is presented in the section 5 .

\section{Review of related literature}

The link between oil price and stock returns has great significance for net oil exporting and net oil importing countries. There are two strands of literature related to the oil price movement and stock returns. The first measures changes in oil price on the returns of the stock of individual companies and the other strand relates this movement to the industry returns.

However, for oil exporting countries, movement in oil prices have theoretically and empirically positive impact on stock returns. Basher and Sadorsky $(2006)^{16}$ using a multifactor model showed that risk of the oil prices influenced the returns of the stock market of the different emerging economies. Park and Ratti $(2008)^{17}$ found positive as well as significant association between movement of oil prices and stock return in Norway. They negative relationship for the other various European countries. The main problem with the previous different studies is that all those studies have just studied the behavior of stock market as whole and did not focused the behavior of individual sectors of the stock market on the economy.

The available literature shows that economic activity as well as real stock returns of the countries that are dependent on oil are mostly affected by the adjustments in the prices of oil see Sadorsky $(1999)^{18}$. Similarly, there are various sectors operating in the stock market and all of them have different exposure to the risk of oil prices (see Ghoilpour, $2011^{19}$ ). The result of Faff and Brailsford $(1999)^{20}$ for 24 different industries of Australia for the period of years 1983 to 1996. They found a positive and significant impact of prices of oil on stock returns. On the other hand, Hammoudeh and Li $(2005)^{21}$ observed the relationship between the returns of stock market of two industries that are oil sensitive enterprises including oil and transportation as well as two countries that export oil including Mexico and Norway with the prices of oil and capital market of the world. Finding of this paper suggest negative relationship between capital market of the world and growth in the oil price.

However, the literature related to the impact of oil prices on stock return for oil importing countries shows inverse relationship between oil prices and stock returns. For instance

\footnotetext{
${ }^{16}$ Basher, Syed A., and Perry Sadorsky."Oil price risk and emerging stock markets." Global finance journal 17, No. 2 (2006): 224-251

${ }^{17}$ Park, Jungwook, and Ronald A. Ratti."Oil price shocks and stock markets in the US and 13 European countries." Energy economics 30, no. 5 (2008): 2587-2608

${ }^{18}$ Sadorsky, Perry. "Oil price shocks and stock market activity." Energy economics 21, no. 5 (1999): 449-469

${ }^{19}$ Ghoilpour, Hassan Fereidouni. "The Effect of Energy Prices on Iranian Industry Stock Returns.” Review of Middle East Economics and Finance 7, no. 1 (2011): 32-51

${ }^{20}$ Faff, Robert W., and Timothy J. Brailsford."Oil price risk and the Australian stock market.” Journal of Energy Finance \& Development 4, no. 1 (1999): 69-87.

${ }^{21}$ Hammoudeh, Shawkat, and Huimin Li. "Oil sensitivity and systematic risk in oil-sensitive stock indices." Journal of Economics and Business 57, no. 1 (2005): 1-21.
} 
Huang et al. (1996) $)^{22}$ observed the negative relationship between returns of the stock market and oil prices. Henriques and Sadorsky $(2008)^{23}$ in their research they studied about the use of alternative energy sources and technology of the firms for the period of January 2001 to May 2007 and according to the results of this research study changes in the valued of the stock of technology firms had a very large impact on the prices of the stock of the alternative firms of the energy as compare to the oil prices.

Moreover, results of the various research studies indicate that shocks of the oil prices have a very significant affect in order to determine the returns of the stock Market indices of the China but rather they did for the index of the manufacturing and some of the oil firms. According to the McSweeney and Worthington (2008) ${ }^{24}$, stock market can be defined as the systematic risk that contributed towards providing the information about the different behavior of the prices of stock. The researchers had utilized a multifactor model and observed that returns of the stock as the most dominant factor as compare to the prices of oil in order to explain the stock returns of the industries of an Australian economy.

Although many studies have linked the oil prices and macroeconomic variables, but still a very small literature available related to the effect of oil prices on sectorial stock returns. Especially, for the countries like Pakistan, there is dearth of studies examining the relationship between oil price movement and stock return. Few studies for example, Arshad and Bashir $(2015)^{25}$ using multifactor model and panel regression have determined the impact of oil prices and stock returns for energy intensive sectors of Pakistan.

Moreover, study by Oberndorfer $(2009)^{26}$ observed the impact of the developments of the energy market, that includes industries of crude oil, coal, gas and other energy utilities companies. The results of the study indicate a negative relationship between increased prices of the oil and returns on the stock market of energy utilities and a positive relationship was examined between oil prices and stock returns of the crude oil companies. In case of the prices of gas, no relationship was observed whereas changes in the prices of the coal have a very little impact on the prices of the stock of the European energy utilities. The study Narayan and Sharma $(2011)^{27}$ using the data of the firm operated in US by focusing on total 560 firms from 14 sectors of the New York Stock Exchange show that the response of the firms to the changes in the price of oil is heterogeneous and this response depends on the sector as well as on the size of the firms.

${ }^{22}$ Ibid.

${ }^{23}$ Sadorsky, Perry, and Irene Henriques. "Multifactor risk and the stock returns of Canadian paper and forest products companies." Forest Policy and Economics 3, no. 3-4 (2001): 199-208.

${ }^{24} \mathrm{McS}$ weeney, Evan J., and Andrew C. Worthington. "A comparative analysis of oil as a risk factor in Australian industry stock returns, 1980-2006." Studies in economics and finance 25, no. 2 (2008): 131-145.

${ }^{25} \mathrm{Ibid}$.

${ }^{26}$ Oberndorfer, U. (2009). Energy prices, volatility, and the stock market: Evidence from the Eurozone. Energy Policy, 37(12), 5787-5795.

${ }^{27}$ Ibid. 
Phan et al $(2015)^{28}$ using top twenty listed firms from five different sectors of the United States that included consumption, truck transport, air transport, chemical manufacturing and petroleum, showed that the increase in the prices of oil resulted in the appreciation in the prices of stock of oil producer. Bouri et al.,(2016) ${ }^{29}$ studied the mean and variance causality between the oil prices and sectoral equity returns in Jordan before and after the Arab uprising and finding suggest that oil shocks significantly affect the service and financial sectors and insignificant in other sector.

In view of aforementioned literature, this paper contributes as follows: Firstly, we use monthly data to compute the impact of oil price changes on stock returns, which in our view will be able to capture oil price changes better as compared to quarterly data, to investigate the effect of changing oil prices in Pakistan on stock returns. Secondly, this paper calculates the impact of changes in oil prices and their stock returns for different non-financial sectors listed in Pakistan stock exchange. Then sectoral analysis will be able to distinguish its effect on different kind of economic activities like exchange rate and interest rate. For this purpose, we have selected 27 sectors listed on Pakistan stock exchange that are directly or indirectly affected by the oil price changes.

\section{Data and Methodology}

Earlier examinations related to the causal relationship between oil price and stock exchange have depended on the conventional Granger causality in mean test. Hafner and Herwartz, $(2008)^{30}$ in their study used multivariate GARCH models both in mean and variance. Choi and Hammoudeh $(2010)^{31}$ have used DCC-GARCH model to ascertain the relationship between Brent oil, WTI oil, copper, gold and silver with S\&P500 index. Similarly, Filis et al. (2011) s2 $^{32}$ used DCC-GARCH-GJR approach to investigate the relationship between oil price movement and stock market movement of Canada, Mexico, Brazil, USA, Germany and Netherlands. Furthermore, Bouri et al. (2016) ${ }^{33}$ applied CCF-GARCH approach to investigate mean and variance causality between the oil prices and sectorial returns of equity in Jordan.

In this study we use conventional multifactor model and applied pooled OLS, random effect and fixed effect regression to facilitate empirical research of share price relationship with fluctuations in oil prices on stock returns. Fluctuation is likely to impact on all industrial sector of the countries (see Sadorsky and Henriques, 2001, El-Sharif et al., 2005) $)^{34}$.

${ }^{28} \mathrm{Ibid}$.

${ }^{29} \mathrm{Ibid}$.

${ }^{30}$ Hafner, Christian M., and Helmut Herwartz."'Testing for causality in variance using multivariate GARCH models." Annalesd'Economieet de Statistique (2008): 215-241.

${ }^{31}$ Choi, Kyongwook, and ShawkatHammoudeh."Volatility behavior of oil, industrial commodity and stock markets in a regime-switching environment." Energy Policy 38, no. 8 (2010): 4388-4399.

${ }^{32}$ Filis, George, Stavros Degiannakis, and Christos Floros. "Dynamic correlation between stock market and oil prices: The case of oil-importing and oil-exporting countries." International Review of Financial Analysis 20, no. 3 (2011): 152-164.

${ }^{33} \mathrm{Ibid}$.

${ }^{34}$ Ibid. 
Moreover, we have selected month end observation of 321 firms of 27 non- financial sectors operates in Pakistan stock market. Furthermore, we include only those firms that have at least 30 days of trading in a calendar year (see Lee and Cheong,2001) ${ }^{35}$, we have selected 24 months of trading period covering from April 2014 to March 2016 Inclusive. Firstly, we calculated average monthly closing prices of the stocks of 321 firm's stock returns. Moreover, reason for selecting this time period is that crude oil price is showed drastic changes over the past two years and as an oil importing country our economy is heavily depend upon on crude oil price movement.

Moreover, average monthly crude oil prices spot of London Brent Crude Oil in US dollar used for oil price movement indication. Average of closing all Pakistan Stock exchange share index is used to find out market portfolio return, average monthly US\$ exchange rate in terms of Pakistani rupee has been used to find out exchange rate return and average monthly reorder purchase rate (REPO) used as risk free rate. All these data has been collected from websites of Pakistan stock exchange, Bloomberg and State bank of Pakistan. Similarly, expected signs of the explanatory variables with respect to dependent variable are explained in the table-2.

${ }^{35}$ Lee, Jason, and H. Yi Cheong."Trade size and information-motivated trading in the options and stock markets." Journal of Financial and Quantitative Analysis 36, no. 4 (2001): 485-501. 
Base Equation:

$$
E S R_{i, t}=a_{1}+a_{2} E M R_{i, t}+a_{3} O i l_{i, t}+a_{4} F x_{i, t}+\varepsilon
$$

Table-2: Description of Variables

\begin{tabular}{|c|c|c|c|c|c|}
\hline $\begin{array}{l}\text { VARIABLE } \\
\text { S }\end{array}$ & $\begin{array}{l}\text { VARIABLE } \\
\text { DESCRIPTIO } \\
\mathrm{N}\end{array}$ & $\begin{array}{l}\text { VARIABLE } \\
\text { CALCULATION }\end{array}$ & $\begin{array}{l}\text { TIME } \\
\text { PERIO } \\
\text { D }\end{array}$ & $\begin{array}{l}\text { EXPECTE } \\
\text { D SIGNS }\end{array}$ & DATA SOURCE \\
\hline$E S R_{i, t}$ & $\begin{array}{c}\text { Excess } \\
\text { monthly } \\
\text { stock return } \\
\text { of security } i \\
\text { at time } t\end{array}$ & $\begin{array}{l}E S R_{i, t}=\text { SR-OMO } \\
\text { SR=LN }\left(\text { Firm }_{t} /\right. \\
\left.\text { Firm }_{t-1}\right) \\
\text { OMO= Open } \\
\text { Market Operation } \\
\text { rate }\end{array}$ & $\begin{array}{l}\text { April- } \\
2014 \\
\text { to } \\
\text { March } \\
-2016\end{array}$ & Negative & $\begin{array}{l}\text { www.psx.com.p } \\
\underline{\mathrm{k}} \\
\underline{w} \text { ww.sbp.org }\end{array}$ \\
\hline$E M R_{i, t}$ & $\begin{array}{l}\text { Excess } \\
\text { monthly } \\
\text { market } \\
\text { return of the } \\
\text { all share } \\
\text { index at } \\
\text { time } t\end{array}$ & $\begin{array}{l}E M R_{i, t}=\mathrm{MR}-\mathrm{OMO} \\
\mathrm{MR}=\mathrm{LN}( \\
\text { Market }_{I, t} / \\
\left.\text { Market }_{I, t-1}\right) \\
\mathrm{OMO}=\text { Open } \\
\text { Market Operation } \\
\text { rate }\end{array}$ & $\begin{array}{l}\text { April- } \\
2014 \\
\text { to } \\
\text { March } \\
-2016\end{array}$ & Positive & $\begin{array}{l}\text { Www.psX.com.p } \\
\underline{\mathrm{k}} \\
\underline{\mathrm{wWw} . \mathrm{sbp} . \mathrm{org}}\end{array}$ \\
\hline $\mathrm{Oil}_{i, t}$ & $\begin{array}{l}\text { Brent Crude } \\
\text { Oil WTI in } \\
\text { US dollar }\end{array}$ & $\begin{array}{ll}\mathrm{Oil}_{I, t}= & \mathrm{LN} \\
\left(\mathrm{Oil}_{t} / \mathrm{Oil}_{t-1}\right) & \end{array}$ & $\begin{array}{l}\text { April- } \\
2014 \\
\text { to } \\
\text { March } \\
-2016\end{array}$ & Negative & www.sbp.org \\
\hline$F x_{i, t}$ & $\begin{array}{c}\text { US\$ } \\
\text { exchange } \\
\text { rate in terms } \\
\text { of PKR. }\end{array}$ & $\begin{array}{l}F x_{I, t}=\text { LN } \quad\left(F x_{t} /\right. \\
\left.F x_{t-1}\right)\end{array}$ & $\begin{array}{c}\text { April- } \\
2014 \\
\text { to } \\
\text { March } \\
-2016\end{array}$ & Negative & www.sbp.org \\
\hline
\end{tabular}

\section{Data Analysis}

This study is based on the relationship between oil prices changes and stock returns of the firms operated in Pakistan in 27 sectors of Pakistan stock exchange (PSX).

\section{Descriptive Statistics}

In Table 3 represent the descriptive statistics of the variables that has been used in our analysis of the impact of oil price on stock return. It can be observed in Table 4.1 excess monthly stock return is ranges from $-170 \%$ to $172 \%$ with mean value of $-0.83 \%$, median $0.09 \%$ and standard deviation $14.55 \%$. For examine the excess market return in the sample, it can be viewed it ranges from $-10.15 \%$ to $-6 \%$ with mean value is $-7.8 \%$, median $-7.25 \%$ and standard deviation $-1.5 \%$.Furthermore, oil price changes is ranges 
from $-25.29 \%$ to $18.66 \%$ with mean value of $-4.15 \%$, median- $4.12 \%$ and standard deviation $11.45 \%$ and foreign exchange is ranges from $-0.99 \%$ to $2.24 \%$ with mean value of $0.34 \%$, median $0.14 \%$ and standard deviation of $0.76 \%$ over the sample period.

Table 3: Descriptive Statistics

\begin{tabular}{|c|l|l|l|l|l|}
\hline \multicolumn{6}{|c|}{ Descriptive Statistics for multivariate analysis } \\
\hline Variables & Mean & Median & Std.Dev & Max & Min \\
\hline $\boldsymbol{E S} \boldsymbol{R}_{\boldsymbol{i}, \boldsymbol{t}}$ & -0.0838 & -0.0894 & 0.1455 & 1.7176 & -1.6990 \\
\hline $\boldsymbol{E M} \boldsymbol{R}_{\boldsymbol{i}, \boldsymbol{t}}$ & -0.0797 & -0.0725 & 0.0152 & -0.05914 & -0.1015 \\
\hline $\boldsymbol{O i l}_{\boldsymbol{i}, \boldsymbol{t}}$ & -0.0415 & -0.0412 & 0.1145 & 0.1866 & -0.2529 \\
\hline $\boldsymbol{F x}_{\boldsymbol{i}, \boldsymbol{t}}$ & 0.0034 & 0.0014 & 0.0076 & 0.0224 & -0.0099 \\
\hline
\end{tabular}

Source: Author's estimations

Table 4 details the correlation matrix of the variables that has been used in regression analysis. Overall, examination of Table 4.2 discloses that nothing with respect to multicollinearity in the sample data and it's includes the representation of all the stocks selected for analysis from 27 sectors of Pakistan stock exchange (PSX).

Table 4: Correlation Matrix

\begin{tabular}{|c|c|c|c|c|}
\hline & $E S R_{i, t}$ & $E M R_{i, t}$ & $O i l_{i, t}$ & $F x_{i, t}$ \\
\hline$E S R_{i, t}$ & 1.0000 & & & \\
\hline$E M R_{i, t}$ & 0.1355 & 1.0000 & & \\
\hline$O i l_{i, t}$ & -0.0224 & 0.1469 & 1.0000 & \\
\hline$F x_{i, t}$ & -0.1035 & -0.2098 & 0.2049 & 1.0000 \\
\hline
\end{tabular}

Source: Author's estimations.

\section{Regression Analysis Results}

In Table-5 for the regression output of three factor model that is our base regression model outline in eq.1 covering the period from April-2014 to March-2016 that shows a positive significant result to aggregate excess market return, and negative significant result with changes in oil prices and exchange rate at $1 \%$ significance level these finding were consistent with previous studies (Huang et al. 1996: Faff and Brailsford ,1999; Park 
and Ratti, 2007; Arouriand Nguyen, 2010;Elyasiani et al., 2011; Arouri et al., 2012; Arshad and Bashir,2014; Bouri et al. 2016) ${ }^{36}$.

Table 5: Regression Analysis (Base Equation)

\begin{tabular}{|c|c|c|c|}
\hline & $\begin{array}{c}\text { (Pooled } \\
\text { Regression) }\end{array}$ & (Fixed Effect) & (Random Effect) \\
\hline VARIABLES & esr & esr & esr \\
\hline \multirow[t]{2}{*}{ Emr } & $1.189 * * *$ & $1.189 * * *$ & $1.189 * * *$ \\
\hline & $(0.0936)$ & $(0.0936)$ & $(0.0936)$ \\
\hline \multirow[t]{2}{*}{ ln_oil_price } & $-0.0328 * * *$ & $-0.0328 * * *$ & $-0.0328 * * *$ \\
\hline & $(0.0128)$ & $(0.0128)$ & $(0.0128)$ \\
\hline \multirow[t]{2}{*}{ ln_exch_rate } & $-1.378 * * *$ & $-1.378 * * *$ & $-1.378 * * *$ \\
\hline & $(0.226)$ & $(0.226)$ & $(0.226)$ \\
\hline \multirow[t]{2}{*}{ Constant } & $0.0138 *$ & $0.0138^{*}$ & $0.0138 *$ \\
\hline & $(0.00761)$ & $(0.00745)$ & $(0.00761)$ \\
\hline Observations & 7,383 & 7,383 & 7,383 \\
\hline R-squared & & 0.026 & \\
\hline Number of comp & 321 & 321 & 321 \\
\hline
\end{tabular}

Source: Author's estimations.

Robust standard errors in parentheses

$$
* * * \mathrm{p}<0.01, * * \mathrm{p}<0.05, * \mathrm{p}<0.1
$$

Moreover, Table-6 explain sectoral analysis of the firms operated in Pakistan Stock Exchange (PSX). Out of 27 sectors 15 sectors show positive significant results for excess market return. Out of the rest of the 10 sectors are affected by the stock exchange volatility at different level of significance. Previous investigations also show that the Oil and Gas sector, and Mining sector are affected by the increase in oil prices. For example, Transportation, Manufacturing, Food, Chemicals, Pharmaceutical, Computer, Real Estate and General services. The results for the Power generation, Construction and financial sectors segments are ambiguous. It is found that there is a significant outcome of the oil prices on oil-related and oil-substitute sectors, a negative impact on oil-utilizing divisions and not a huge impact on non-oil-related segments like financial sector.(Broadstock and Filis, 2014) $)^{37}$. 
Table 6: Regression Analysis (Sectoral Analysis)

\begin{tabular}{|c|c|c|c|c|c|}
\hline & Sectors & EMR & $\begin{array}{l}\text { LOG_Oil } \\
\text { Prices }\end{array}$ & $\begin{array}{l}\text { LOG_Exchang } \\
\text { e rate }\end{array}$ & $\begin{array}{l}\text { Obser- } \\
\text { vations }\end{array}$ \\
\hline 1. & $\begin{array}{l}\text { AUTOMOBILE } \\
\text { ASSEMBLER }\end{array}$ & $\begin{array}{l}0.804 \\
(0.547)\end{array}$ & $\begin{array}{l}0.230 * * * \\
(0.0527)\end{array}$ & $\begin{array}{l}-3.380 * * * \\
(0.667)\end{array}$ & 299 \\
\hline 2. & $\begin{array}{l}\text { AUTOMOBILE PARTS \& } \\
\text { ACCESSORIES }\end{array}$ & $\begin{array}{l}-1.091 \\
(1.170)\end{array}$ & $\begin{array}{l}-0.110 * \\
(0.0442)\end{array}$ & $\begin{array}{l}-0.393 \\
(1.254)\end{array}$ & 115 \\
\hline 3. & $\begin{array}{l}\text { CABLE \& ELECTRICAL } \\
\text { GOODS }\end{array}$ & $\begin{array}{l}2.300 * * * \\
(0.482)\end{array}$ & $\begin{array}{l}0.113 \\
(0.0799)\end{array}$ & $\begin{array}{l}-0.441 \\
(0.763)\end{array}$ & 115 \\
\hline 4. & CEMENT & $\begin{array}{l}1.706^{* * * *} \\
(0.344)\end{array}$ & $\begin{array}{l}-0.0226 \\
(0.0385)\end{array}$ & $\begin{array}{l}-4.896^{* * * *} \\
(0.765)\end{array}$ & 437 \\
\hline 5. & CHEMICAL & $\begin{array}{l}0.688 * * \\
(0.277)\end{array}$ & $\begin{array}{l}-0.0984 * * * \\
(0.0338)\end{array}$ & $\begin{array}{l}-1.541 * * \\
(0.590)\end{array}$ & 575 \\
\hline 6. & ENGINEERING & $\begin{array}{l}0.949^{*} \\
(0.523)\end{array}$ & $\begin{array}{l}-0.0860^{*} \\
(0.0452)\end{array}$ & $\begin{array}{l}0.498 \\
(0.515)\end{array}$ & 276 \\
\hline 7. & FERTILIZER & $\begin{array}{l}0.425^{*} \\
(0.228)\end{array}$ & $\begin{array}{l}-0.0980^{*} \\
(0.0423)\end{array}$ & $\begin{array}{l}-4.107 * * * \\
(0.818)\end{array}$ & 138 \\
\hline 8. & $\begin{array}{l}\text { FOOD \& PERSONAL CARE } \\
\text { PRODUCTS }\end{array}$ & $\begin{array}{l}0.650 \\
(0.437)\end{array}$ & $\begin{array}{l}0.0747 \\
(0.0457)\end{array}$ & $\begin{array}{l}-2.655^{* * * *} \\
(0.880)\end{array}$ & 414 \\
\hline 9. & GLASS \& CERAMICS & $\begin{array}{l}2.571 * * * \\
(0.588)\end{array}$ & $\begin{array}{l}-0.198 \\
(0.128)\end{array}$ & $\begin{array}{l}-2.249 * * \\
(0.904)\end{array}$ & 184 \\
\hline 10. & JUTE & $\begin{array}{c}1.866 \\
(1.031)\end{array}$ & $\begin{array}{l}0.378^{*} \\
(0.123)\end{array}$ & $\begin{array}{l}-0.214 \\
(1.210)\end{array}$ & 69 \\
\hline 11. & LEATHER \& TANNERIES & $\begin{array}{l}0.562 \\
(1.080)\end{array}$ & $\begin{array}{l}-0.115 \\
(0.0497)\end{array}$ & $\begin{array}{l}-4.600 \\
(4.349)\end{array}$ & 69 \\
\hline 12. & MISCELLANEOUS & $\begin{array}{l}1.207 \\
(0.792)\end{array}$ & $\begin{array}{l}-0.0893^{*} \\
(0.0459)\end{array}$ & $\begin{array}{l}0.149 \\
(0.994)\end{array}$ & 184 \\
\hline 13. & $\begin{array}{l}\text { OIL \& GAS } \\
\text { EXPLORATION } \\
\text { COMPANIES }\end{array}$ & $\begin{array}{l}-0.529 \\
(0.468)\end{array}$ & $\begin{array}{l}0.158 \\
(0.128)\end{array}$ & $\begin{array}{l}-5.307 * * \\
(1.091)\end{array}$ & 92 \\
\hline 14. & $\begin{array}{l}\text { OIL \& } \\
\text { GASMARKETINGCOMPA } \\
\text { NIES }\end{array}$ & $\begin{array}{l}1.193 * * * \\
(0.281)\end{array}$ & $\begin{array}{l}-0.160^{* * * *} \\
(0.0258)\end{array}$ & $\begin{array}{l}-2.025^{* *} \\
(0.651)\end{array}$ & 161 \\
\hline 15 . & PAPER \& BOARD & $\begin{array}{l}0.654 \\
(0.414)\end{array}$ & $\begin{array}{l}-0.0572 \\
(0.0770)\end{array}$ & $\begin{array}{l}-1.614^{*} \\
(0.797)\end{array}$ & 184 \\
\hline 16. & PHARMACEUTICALS & $\begin{array}{l}0.469 \\
(0.498)\end{array}$ & $\begin{array}{l}-0.0599 \\
(0.0470)\end{array}$ & $\begin{array}{l}-1.129 \\
(0.968)\end{array}$ & 207 \\
\hline 17. & $\begin{array}{l}\text { POWER GENERATION \& } \\
\text { DISTRIBUTION }\end{array}$ & $\begin{array}{l}1.605^{* * * *} \\
(0.326)\end{array}$ & $\begin{array}{l}0.0469 \\
(0.0427)\end{array}$ & $\begin{array}{l}-0.791 \\
(0.603)\end{array}$ & 391 \\
\hline 18. & REFINERY & $\begin{array}{l}0.776 \\
(0.696)\end{array}$ & $\begin{array}{l}-0.100 \\
(0.0507)\end{array}$ & $\begin{array}{l}-0.549 \\
(1.701)\end{array}$ & 69 \\
\hline 19. & $\begin{array}{l}\text { SUGAR \& ALLIED } \\
\text { INDUSTRIES }\end{array}$ & $\begin{array}{l}2.175^{* * * *} \\
(0.360)\end{array}$ & $\begin{array}{l}-0.0528 \\
(0.0457)\end{array}$ & $\begin{array}{l}-0.642 \\
(0.699)\end{array}$ & 690 \\
\hline 20. & SYNTHETIC \& RAYON & $\begin{array}{l}2.081 * * * \\
(0.514)\end{array}$ & $\begin{array}{l}-0.105 \\
(0.0916)\end{array}$ & $\begin{array}{l}-1.850 \\
(1.273)\end{array}$ & 184 \\
\hline 21. & TEXTILE COMPOSITE & $\begin{array}{l}1.359^{* * * *} \\
(0.258)\end{array}$ & $\begin{array}{l}-0.0942 * * * \\
(0.0293)\end{array}$ & $\begin{array}{l}-0.243 \\
(0.588)\end{array}$ & 851 \\
\hline 22. & TEXTILE SPINNING & $\begin{array}{l}0.865^{* * * *} \\
(0.192)\end{array}$ & $\begin{array}{l}-0.0785^{* *} \\
(0.0385)\end{array}$ & $\begin{array}{l}-0.953 \\
(0.754)\end{array}$ & 1288 \\
\hline 23. & TEXTILE WEAVING & $\begin{array}{l}1.292 * * \\
(0.406)\end{array}$ & $\begin{array}{l}-0.0651 \\
(0.0763)\end{array}$ & $\begin{array}{l}-0.0145 \\
(1.101)\end{array}$ & 184 \\
\hline 24. & TOBACCO & $\begin{array}{l}2.672 \\
(0.940)\end{array}$ & $\begin{array}{l}0.0342 \\
(0.0964)\end{array}$ & $\begin{array}{l}-1.811 \\
(3.812)\end{array}$ & 69 \\
\hline 25. & TRANSPORT & $\begin{array}{l}2.021^{* *} \\
(0.232)\end{array}$ & $\begin{array}{l}0.0246 \\
(0.0925)\end{array}$ & $\begin{array}{l}-1.305 \\
(2.237)\end{array}$ & 69 \\
\hline
\end{tabular}




\begin{tabular}{|c|l|l|l|l|l|}
\hline \multirow{2}{*}{26.} & VANASPATI \& ALLIED & -0.219 & 0.315 & 7.796 & 46 \\
& INDUSTRIES & $(2.878)$ & $(0.120)$ & $(12.13)$ & \\
\hline 27. & WOOLLEN & 2.562 & -0.108 & -1.016 & 23 \\
& & $(0)$ & $(0)$ & $(0)$ & \\
\hline
\end{tabular}

Robust standard errors in parentheses $* * * \mathrm{p}<0.01, * * \mathrm{p}<0.05, * \mathrm{p}<0.1$

However, in 2015-16 Cotton Crop Assessment Committee (CCAC) slump the cotton production by $30 \%$ (Pakistan Strategy-2016) ${ }^{38}$ and also rose in custom duty on finished polyester staple fiber from $6 \%$ to $10 \%$ (PACRA-2016) ${ }^{39}$ that will be a reason insignificant effect of oil prices on woolen, synthetic and rayon and Jute sectors. Similarly, refining sectors faced challenges in 2015-16 in the shape of volatility in margins an outcome of changes in crude oil prices, introducing simpler technology and exchange rate depreciation (PACRA-2016) ${ }^{40}$. In 2015-16 government of Pakistan raised regulatory duties on 400 luxury on items by up to $20 \%$ (Pakistan Strategy-2016) ${ }^{41}$ that mainly effect food, housing/electricity/gas, clothing \& footwear, transport and tobacco sectors. Moreover, insignificant finding in power generation sector is because Pakistan is facing major challenges like rising of circular debt, expensive and unsustainable fuel mix and Tariff subsidies pressure on fiscal reserve(PACRA-2016) ${ }^{42}$.Similarly, Pharmaceutical sector facing some challenges like Multinational Corporation is exiting from the country because of pricing issues, high operating leverage (PACRA-2016) ${ }^{43}$.

Furthermore, sugar sector is also under facing challenges in local market despite of surplus sugarcane production in Pakistan but government imposing 15\% regulatory duty on export molasses, sugar prices in controlled by government (PACRA-2016) ${ }^{44}$. Similarly, insignificant results in leather and tanners is cause by following issues like high cost of production, energy crises, environmental challenges, high borrowing cost for the sector (PITAD-2016) ${ }^{45}$.In 2014-15 there is a decline of 1.1 percent in production of edible oil because large inventory of ghee and Vanaspati is built by the manufacturer year

${ }^{38}$ Pakistan Strategy (2016).ArifHabib ltd:http://www.arifhabibltd.com/downloads/PakistanStrategy2016.pdf. (accessed August 20, 2017).

${ }^{39}$ PACRA-The Pakistan Credit Rating Agency Limited.(2016). Fertilizer Sector-

2016.http://www.pacra.com.pk/uploads/doc_report/Fertilizer\%20Company.pdf. (accessed August 25, 2017).

${ }^{40}$ PACRA-The Pakistan Credit Rating Agency Limited.(2016). Cement Sector-

2016.http://www.pacra.com.pk/uploads/doc_report/Cement\%20Company.pdf. (accessed August 25, 2017).

${ }^{41}$ Ibid

${ }^{42}$ PACRA-The Pakistan Credit Rating Agency Limited.(2016). Pharmaceutical Sector-

2016.http://www.pacra.com.pk/uploads/doc_report/ Pharmaceutical \%20Company.pdf. (accessed August 25, 2017).

${ }^{43}$ PACRA-The Pakistan Credit Rating Agency Limited.(2016). Chemical Sector-

2016.http://www.pacra.com.pk/uploads/doc_report/ Chemical \%20Company.pdf. (accessed August 26, 2017).

${ }^{44}$ PACRA-The Pakistan Credit Rating Agency Limited.(2016). Refining Sector-2016.

http://www.pacra.com.pk/uploads/doc_report/Refining \%20Company.pdf. (accessed August 26, 2017)

${ }^{45}$ PITAD- Pakistan Institute of Trade Development (2016). Leather sector analysis-2016 http://www.pitad.org.pk/Publications/28-

Pakistan\%20Trade\%20Liberalization\%20Sectoral\%20Study\%20on\%20Leather\%20Sector\%20in\%20Pakistan.p df (accessed August 27, 2017). 
ago to get benefit from depressed input prices which prompted the industry to reduce their production (SBP annual report-2014-15) ${ }^{46}$.

\section{Conclusion and policy implication}

Most of the previous studies have emphasized on the effect of oil price changes on the indexes of aggregate market. This this study investigates the impact of oil price movement on the stock returns related to the different sectors of the stock market. Using multifactor model on the data on Pakistan stock market's 27 sectors ranging from the period between April-2014 and March-2016 inclusive, we find positive and significant association between prices of oil and stock return. The available literature also supports our findings (see for example, Huang et al. 1996: Faff and Brailsford, 1999; Park and Ratti, 2007; Arouri and Nguyen, 2010; Elyasiani et al., 2011; Qinbin and Mohammad, 2012; Arouri et al., 2012; Arshad and Bashir, 2014; Bouri et al. 2016) ${ }^{47}$. Results suggest that movement in oil price cause aggregate change in stock return and market return. However, regression on sectoral level reveal mixed results for different sectors.

The results show that crude oil plays a key role in the stock returns of different sectors. Oil is one of the main factors that contributed towards affecting the unpredictability of profits of the various enterprises. This study is based on investigation of oil price changes and its impact on stock returns of the oil intensive sectors. For future research there are lot more areas should be consider like more macroeconomics variables should be included to investigate the effect of oil price (defined by previous literature). Moreover, effect of oil price can also investigate by comparing Pakistan's stock market with global stock market.

\section{Bibliography}

Abel, Andrew B., and Ben S. Bernanke."Macroeconomics, 4.bs." Boston, San Francisco, New York: Addison Willey Longman inc (2001).

Acaravci, Ali, IlhanOzturk, and SerkanYilmazKandir. "Natural gas prices and stock prices: Evidence from EU-15 countries." Economic Modelling 29, no. 5 (2012): 16461654.

Arshad, RABIA., and ADNAN. Bashir. "Impact of oil and gas prices on stock returns: Evidence from Pakistan's energy intensive industries." International Review of Social Sciences 3, no. 4 (2015): 156-168.

Arouri, Mohamed El Hedi, JamelJouini, and DucKhuong Nguyen. "On the impacts of oil price fluctuations on European equity markets: Volatility spillover and hedging effectiveness." Energy Economics 34, no. 2 (2012): 611-617.

\footnotetext{
${ }^{46}$ State Bank of Pakistan.(2015). Annual Report-2014-15.Statistics and DWH Department.State Bank of Pakistan.http://www.sbp.org.pk/reports/annual/arFY14/Vol1/APR-FY14(complete).pdf (accessed September 26, 2017).

${ }^{47}$ Ibid.
} 
Aloui, Chaker, and Rania Jammazi. "The effects of crude oil shocks on stock market shifts behaviour: A regime switching approach." Energy Economics 31, no. 5 (2009): 789-799.

Aloui, Chaker, DucKhuong Nguyen, and HassenNjeh."Assessing the impacts of oil price fluctuations on stock returns in emerging markets." Economic Modelling 29, no. 6 (2012): 2686-2695.

Backus, David K., and Mario J. Crucini."Oil prices and the terms of trade." Journal of international Economics 50, no. 1 (2000): 185-213.

Broadstock, David C., and George Filis. "Oil price shocks and stock market returns: New evidence from the United States and China." Journal of International Financial Markets, Institutions and Money 33 (2014): 417-433.

Brown, Stephen J., and Toshiyuki Otsuki.A global asset pricing model. Working paper, New York University, (1990):

Brown, Stephen PA, and Mine K. Yücel. "Energy prices and aggregate economic activity: an interpretative survey." The Quarterly Review of Economics and Finance 42, no. 2 (2002): 193-208.

Bouri, Elie. a "Return and volatility linkages between oil prices and the Lebanese stock market in crisis periods." Energy 89 (2015): 365-371.

Bouri, Elie. b "A broadened causality in variance approach to assess the risk dynamics between crude oil prices and the Jordanian stock market." Energy Policy 85 (2015): 271279.

Bouri, Elie, Basel Awartani, and AkthamMaghyereh. "Crude oil prices and sectoral stock returns in Jordan around the Arab uprisings of 2010." Energy Economics 56 (2016): 205214.

Choi, Kyongwook, and ShawkatHammoudeh."Volatility behavior of oil, industrial commodity and stock markets in a regime-switching environment." Energy Policy 38, no. 8 (2010): 4388-4399.

"Economic Survey of Pakistan 2014-15." Islamabad: Government of Pakistan (2015). http://www.finance.gov.pk/survey_1617.html (accessed July 14, 2017).

El-Sharif, Idris, Dick Brown, Bruce Burton, Bill Nixon, and Alex Russell."Evidence on the nature and extent of the relationship between oil prices and equity values in the UK." Energy Economics 27, no. 6 (2005): 819-830.

Elyasiani, Elyas, Iqbal Mansur, and BabatundeOdusami."Oil price shocks and industry stock returns." Energy Economics33, no. 5 (2011): 966-974.

Faff, Robert W., and Timothy J. Brailsford."Oil price risk and the Australian stock market." Journal of Energy Finance \& Development 4, no. 1 (1999): 69-87.

Ferson, Wayne E., and Campbell R. Harvey. "Predictability and time-varying risk in world equity markets." Research in Finance 13 (1995): 25-88. 
Filis, George, Stavros Degiannakis, and Christos Floros. "Dynamic correlation between stock market and oil prices: The case of oil-importing and oil-exporting countries." International Review of Financial Analysis 20, no. 3 (2011): 152-164.

Granger, Clive WJ."Testing for causality: a personal viewpoint." Journal of Economic Dynamics and control 2 (1980): 329-352.

Ghoilpour, Hassan Fereidouni. "The Effect of Energy Prices on Iranian Industry Stock Returns." Review of Middle East Economics and Finance 7, no. 1 (2011): 32-51.

Hammoudeh, Shawkat, and Kyongwook Choi."Behavior of GCC stock markets and impacts of US oil and financial markets." Research in International Business and Finance 20, no. 1 (2006): 22-44.

Hammoudeh, Shawkat, and Huimin Li. "Oil sensitivity and systematic risk in oilsensitive stock indices." Journal of Economics and Business 57, no. 1 (2005): 1-21.

Hamilton, James D. "Oil and the macroeconomy since World War II." Journal of political economy 91, no. 2 (1983): 228-248.

Hafner, Christian M., and Helmut Herwartz."Testing for causality in variance using multivariate GARCH models."Annalesd'Economieet de Statistique (2008): 215-241.

Hooker, Mark A. "Are oil shocks inflationary? Asymmetric and nonlinear specifications versus changes in regime." Journal of Money, Credit and Banking (2002): 540-561.

Huang, Roger D., Ronald W. Masulis, and Hans R. Stoll."Energy shocks and financial markets." Journal of Futures Markets: Futures, Options, and Other Derivative Products 16, no. 1 (1996): 1-27.

Jones, Charles M., and GautamKaul."Oil and the stock markets." The journal of Finance 51, no. 2 (1996): 463-491.

Kaneko, Takashi, and Bong-Soo Lee."Relative importance of economic factors in the US and Japanese stock markets." (1995): 290-307.

Lee, Jason, and H. Yi Cheong."Trade size and information-motivated trading in the options and stock markets." Journal of Financial and Quantitative Analysis 36, no. 4 (2001): 485-501.

Lescaroux, François, and Valérie Mignon."On the influence of oil prices on economic activity and other macroeconomic and financial variables." OPEC Energy Review 32, no. 4 (2008): 343-380.

Maghyereh, Aktham. "Oil price shocks and emerging stock markets: A generalized VAR approach." In Global stock markets and portfolio management, pp. 55-68. Palgrave Macmillan, London, 2006.

McSweeney, Evan J., and Andrew C. Worthington. "A comparative analysis of oil as a risk factor in Australian industry stock returns, 1980-2006." Studies in economics and finance 25, no. 2 (2008): 131-145.

Nandha, Mohan, and Robert Brooks. "Oil prices and transport sector returns: an international analysis." Review of Quantitative Finance and Accounting 33, no. 4 (2009): 393. 
Nandha, Mohan, and Robert Faff. "Does oil move equity prices? A global view." Energy Economics 30, no. 3 (2008): 986-997.

Narayan, Paresh Kumar, and Susan Sunila Sharma."New evidence on oil price and firm returns." Journal of Banking \& Finance 35, no. 12 (2011): 3253-3262.

Oberndorfer, U. (2009). Energy prices, volatility, and the stock market: Evidence from the Eurozone. Energy Policy, 37(12), 5787-5795.

OGRA-Oil and Gas Regulating Authority (2016). Annual Report (201516).https://www.ogra.org.pk/ogra-annual-reports (accessed July 20, 2017).

Pakistan Strategy (2016).ArifHabib ltd: http://www.arifhabibltd.com/downloads/PakistanStrategy2016.pdf. (accessed August 20, 2017).

PACRA-The Pakistan Credit Rating Agency Limited.(2016). Fertilizer Sector-2016. http://www.pacra.com.pk/uploads/doc_report/Fertilizer\%20Company.pdf. (accessed August 25, 2017).

PACRA-The Pakistan Credit Rating Agency Limited.(2016). Cement Sector-2016. http://www.pacra.com.pk/uploads/doc_report/Cement\%20Company.pdf. (accessed August 25, 2017).

PACRA-The Pakistan Credit Rating Agency Limited.(2016). Pharmaceutical Sector2016.http://www.pacra.com.pk/uploads/doc_report/ Pharmaceutical \%20Company.pdf. (accessed August 25, 2017).

PACRA-The Pakistan Credit Rating Agency Limited.(2016). Chemical Sector2016.http://www.pacra.com.pk/uploads/doc_report/Chemical \%20Company.pdf. (accessed August 26, 2017).

PACRA-The Pakistan Credit Rating Agency Limited. (2016). Refining Sector-2016. http://www.pacra.com.pk/uploads/doc_report/ Refining \%20Company.pdf. (accessed August 26, 2017).

PACRA-The Pakistan Credit Rating Agency Limited.(2016). Power distribution Sector2016.http://www.pacra.com.pk/uploads/doc_report/ Power distribution r\%20Company.pdf. (accessed August 26, 2017).

Papapetrou, Evangelia. "Oil price shocks, stock market, economic activity and employment in Greece." Energy economics 23, no. 5 (2001): 511-532.

Park, Jungwook, and Ronald A. Ratti."Oil price shocks and stock markets in the US and 13 European countries." Energy economics 30, no. 5 (2008): 2587-2608.

Phan, Dinh Hoang Bach, Susan Sunila Sharma, and Paresh Kumar Narayan."Oil price and stock returns of consumers and producers of crude oil." Journal of International Financial Markets, Institutions and Money 34 (2015): 245-262.

PITAD- Pakistan Institute of Trade Development (2016). Leather sector analysis-2016 http://www.pitad.org.pk/Publications/28- 
Pakistan\%20Trade\%20Liberalization\%20Sectoral\%20Study\%20on\%20Leather\%20Sect or\%20in\%20Pakistan.pdf (accessed August 27, 2017).

Sadorsky, Perry. "Oil price shocks and stock market activity." Energy economics 21, no. 5 (1999): 449-469.

Sadorsky, Perry, and Irene Henriques. "Multifactor risk and the stock returns of Canadian paper and forest products companies." Forest Policy and Economics 3, no. 3-4 (2001): 199-208.

Sadorsky, Perry. "Correlations and volatility spillovers between oil prices and the stock prices of clean energy and technology companies." Energy Economics 34, no. 1 (2012): 248-255.

State Bank of Pakistan.(2015). Annual Report-2014-15.Statistics and DWH Department.State Bank of Pakistan.

http://www.sbp.org.pk/reports/annual/arFY14/Vol1/APR-FY14(complete).pdf (accessed September 26, 2017).

Tsai, Chun-Li. "How do US stock returns respond differently to oil price shocks precrisis, within the financial crisis, and post-crisis?." Energy Economics 50 (2015): 47-62. 